\title{
QUALITATIVE ANALYSIS OF NATURAL TERROIR UNITS. CASE STUDY: MODRA WINE RAYON (SLOVAKIA)
}

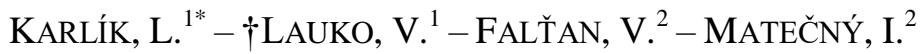

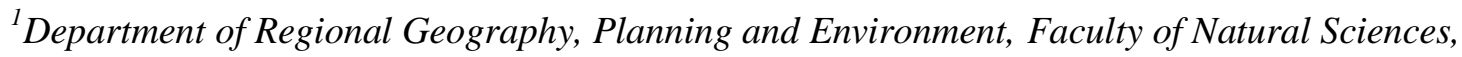 \\ Comenius University in Bratislava \\ Ilkovičova 6, Mlynská Dolina, 84215 Bratislava 4, Slovakia \\ (phone: +421-908-081-951; fax: +421-2-6542-9064) \\ ${ }^{2}$ Department of Physical Geography and Geoecology, Faculty of Natural Sciences, Comenius \\ University in Bratislava \\ Ilkovičova 6, Mlynská Dolina, 84215 Bratislava 4, Slovakia \\ (phone: +421-2-6029-6518) \\ *Corresponding author \\ e-mail:karlik3@uniba.sk \\ (Received $9^{\text {th }}$ Aug 2017; accepted $5^{\text {th }}$ Feb 2018)
}

\begin{abstract}
The importance of the terroir concept is rapidly increasing not only because consumer interest in the origin of the product, but also because of winemaker's interest in qualitatively high and unique wine production. The main aim of the article is to present a methodological framework of Natural terroir units (NTU's) for countries which still do not have applied French appellation system. The study depicts a logical framework consisting of natural terroir factors selection, followed by data reclassification, encoding and the final data composition and utilization. In this work, we identified and described 182 regional types in 362 NTU's in the Modra wine rayon. In the final stage were selected the most valuable vineyard sites for Green Veltliner using NTU coding system. The findings were subsequently compared to results which were obtained by decades lasting empirical observations in the study area conducted by enologist and winemakers. Most of the selected NTU's matched to empirical study results. Identification is proven in the GIS environment; this is considered the most useful instrument because of its ability to manipulate spatial data and perform spatial analysis.
\end{abstract}

Keywords: coding system, empirical validation, vineyards, GIS, map composition

\section{Introduction}

Wine character differs from continent to continent, country to country, region to region, even vineyard to vineyard, and of course from producer to producer. These differences are affected by countless variables inherited from natural conditions, processing techniques, cultivar selection, tradition and human factors which are difficult to define. The specific natural and human aspects form unique areas called terroir, and their possible combinations imprint persistent and invariable specificity on the product. Therefore, understanding terroir carries explicit regional recognition for every product, and generates not only opportunity, but more importantly, product demand and its propagation in the market place.

Terroir is the complex of geographical conditions which give wine its specific taste and distinguishes it from others. The term "terroir" is recognized and revered throughout the viticulture world because it embraces the influence of natural landscape properties; including geology, soil, topography and climate. It determines the most suitable wine variety for each particular site, and also the technical processes of wine makers; including the use of autochthonous microorganisms during fermentation (Van 
Leeuwen et al., 2004). No other agricultural product has such a strong relationship with the soil as wine (Van Leeuwen, 2010). For instance, top-rated Cabernet Sauvignon wines in Catalonia came from soil with a more limited water regime, and its success was most likely due to accumulation of the phenolic compounds responsible for wine color and taste (Ubalde et al., 2010). Climate there affected almost all variables of grape composition - berry weight, grape-ripening speed and wine composition. Terroir labelled wines generally have greater demand than non-terroir varieties because consumers are interested in place of origin, and they want information before they buy. Terroir-identified products also carry a guarantee of quality under strict control of national authorities. According to California Wine Industry (2016), the Slovak Republic produced $376,270 \mathrm{hl}$ of wine in 2016 . Although this quantity is negligible compared to the largest producers from France $(46,701,000 \mathrm{hl})$, Italy $(44,739,000 \mathrm{hl})$, Spain $(38,200,400 \mathrm{hl})$. Slovakia cannot be considered a "small wine country"; judging on its world-competition wine results (Ďurčová, 2013, 2014).

At the highest level, the total vine-growing area in Slovakia is subdivided into 6 vineyard regions (Fig. 1). There is then the lower level of 40 wine rayons (zones) created by 511 vine-growing settlements (ÚKSUP, 2015). The traditional labelling system used here is a tribute to the historical influence of the prior German population. This system concentrated on sugar content and thus distinguished between wine categories. However, updated legislative framework (NRSR, 2009) has determined that sugar content is not the only relevant characteristic of wine quality, and European Union influence has seen Slovak viticulture approach French wine categorization. This categorization accounts for the precise grape origin; especially in which vineyard the grape ripened and what conditions were uniquely characteristic of this particular allotment.

This principle has been applied traditionally in France for centuries, and it clearly indicates which vineyards are qualitatively the best. At this stage, no final appellation system is legislated for Slovakia, so labelling may be based on either place of origin or on wine attributes.

Complete use of French labelling and abandonment of the German system has received threats concerning recognition of the place of origin. There are only several products labelled under the French principle in Slovakia, and while these products are registered in the DSC (Districtus Slovakia Controlatus) appellation system which is similar to the French AOC (Appelation d' origine contrôlée), geographic conditions are not appropriately indicated in the DSC. Accurate mapping of agricultural landscapes including vineyards and their potential evaluation is often performed in geographic information systems (Irimia and Patriche, 2010; Irimia et al., 2012; Masný and Zaušková, 2015; Incze and Novák, 2016). However, there is a lack of terroir research providing understanding of Slovak viticulture areas. Wine regions have very good soils, the climate and ecological conditions to equal well-known European vineyards, but many have been transformed into building areas, and also abandoned (Pospíšilová et al., 2005a). Modern GIS technology and remote sensing present new opportunities in terroir mapping (Johnson et al., 2012), and positive results and technological progress have encouraged increased interest in terroir study and identification in many wine-producing countries.

From above mentioned, we can postulate our hypothesis which assumes that, there are homogenous natural spatial units in viticultural landscape which have impact on wine character. 


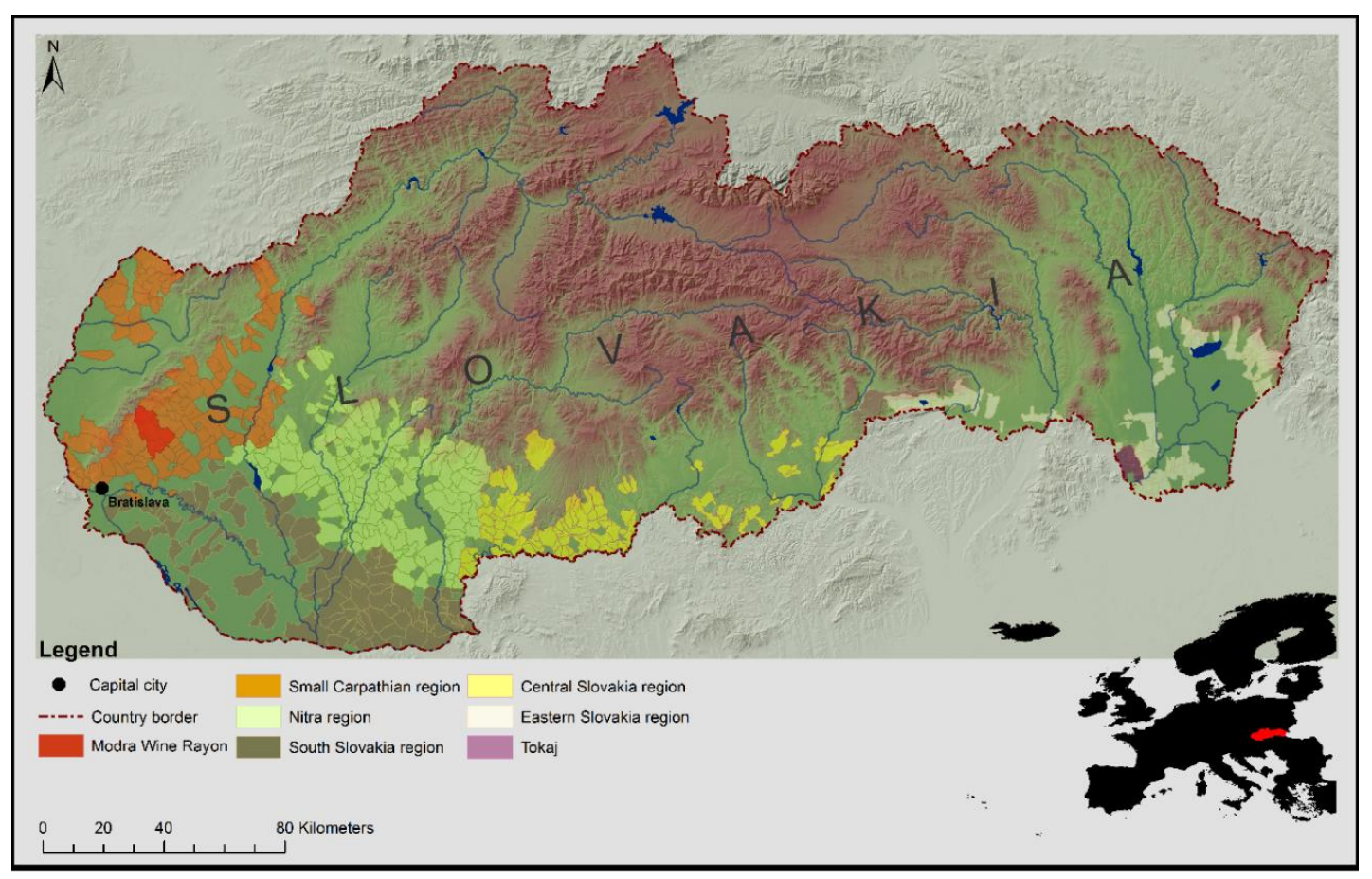

Figure 1. Map with the location of the Modra wine rayon relative to other major grape growing regions in Slovakia (NRSR, 2009)

The importance of terroir unit identification comes from resolution of OIV - Office International de la Vigne et du Vin - concerning the identification of terroir in all countries where wine is produced. Carey et al., 2002 argue that, terroir research provides producers better understanding of their vineyards and improves their quality. An NTU map is more useful than a soil map because it relates all the natural factors influencing wine production. The aim of presented study is to create methodological approach to identify NTU as the basis for complex terroir. The secondary aim of this study is to highlight the application of these units in further geographical/geoecological research and to perform validation of the delimited NTU's with empirical research executed in the study area in last decades.

Different authors identify natural terroir elements differently and give unequal weight to certain aspects (Carey et al., 2002; Vadour, 2002; Pospíšilová et al., 2005a; Tomasi et al., 2013). Most work has been performed in GIS; enabling working with more spatial variables, assessment of viticulture potential and landscape suitability and identification of homogenous production zones. For example the following authors employed GIS in their terroir work; (a) (Boyer and Wolf, 1998, 2000) used GIS to study viticulture potential, and they applied combined geographical information for vineyard suitability in Virginia USA; (b) Jones et al. (2004) analyzed terroir potential in the Umpqua Valley in Oregon; (c) Jones (2006) assessed viticulture potential in the Oregon Rogue River area; (d) Chen (2011) used complex analysis of nine variables to determine terroir suitability in Nebraska; (e) (Magarey et al., 1998; Jones and Duff, 2003) predicted potential in new areas of existing viticultural regions and (f) Imre and Mauk (2003) characterized terroir in New Zealand.

Both regional characterization and suitability modelling are limited by data availability and scale (Vadour, 2002; Van Leeuwen et al., 2004). This especially applies 
to the Slovak Republic and several other post-communist countries which have potential to develop their viticulture due to global climate change. Table 1 shows overview of the used natural factors in selected terroir studies.

Table 1. Overview of the selected natural factors in recent studies. Highlighted available factors were used in our study

\begin{tabular}{c|c}
\hline Author & Selected natural factors \\
\hline Bonfrante et al. (2011) & $\begin{array}{c}\text { Elevation, slope, geological unit, soil texture, } \mathrm{CaCo}_{3}, \mathrm{pH}, \text { soil organic } \\
\text { matter, available water capacity, }\end{array}$ \\
\hline Carey et al. (2008) & Landform, aspect, elevation, soil type, geological unit \\
\hline Falt'an et al. (2016) & $\begin{array}{c}\text { Landform, soil substrate (geological unit), slope angle, soil type, } \mathrm{pH}, \\
\text { carbonates (\%), nitrogen (\%) }\end{array}$ \\
\hline Falt'an et al. (2017) & $\begin{array}{c}\text { Landform, soil substrate (geological unit), soil type, slope, solar radiation, } \\
\text { aspect }\end{array}$ \\
\hline Irimia et al. (2012) & $\begin{array}{c}\text { Slope, aspect, annual average temperature, the hottest month average } \\
\text { temperature, growing degree days, solar insolation, average rainfall for the } \\
\text { period from 1st April to 30 September, soil texture, humus content, the length } \\
\text { of bioactive period }\end{array}$ \\
\hline Jones et al. (2004) & $\begin{array}{c}\text { Elevation, slope, aspect, drainage, available water capacity, soil depth, pH, } \\
\text { growing degree days }\end{array}$ \\
\hline Sarmento et al. (2006) & \begin{tabular}{c} 
Elevation, slope, aspect \\
\hline
\end{tabular}
\end{tabular}

Climatic data is especially important in cultivar selection because each cultivar needs specific total temperature to complete its vegetation cycle (Huglin, 1986; Carey, 2005). Hence, planting late-ripening cultivars in colder regions precludes it from finishing its vegetation cycle. The lower temperature limit for viticulture without winter protection is considered to be $-1{ }^{\circ} \mathrm{C}$ of the coldest month's mean temperature (Gladstones, 2000). In contrast, faster ripening cultivars in warmer regions lose production quality because of over-growth. The generally accepted temperature for grapevine requisites is $10^{\circ} \mathrm{C}$ and above; where the vegetation cycle responsible for further production commences (Homolová and Kropáč, 1993). This $10^{\circ} \mathrm{C}$ is therefore often used in calculations evaluating viticulture regions in climatic indexes such as Huglin and "growing-degreedays".

Geology affects the bouquet and taste of wine, and although bedrock generally asserts less impact on wine and its quality than topographic, soil and climatic components (Hugett, 2005). While bedrock influence occurs in shallow sandy soils (Záruba and Homolová, 1985) and affects older plants more; with their deeper root system giving essential nutrients more frequently than the soil layer, some authors are adamant that geology should be considered separately from soil.

Humid soils and excessive irrigation can yield a relatively small undeveloped root system; with excess water precluding a vigorous root system and reducing the capacity to store starch in subsequent seasons (Atkinson, 2011). However, soil does affect wine character and quality, and it is extremely difficult to separate it from the geological effect emanating from bedrock. The following elements are most frequently assessed in terroir: soil chemistry, temperature, texture, depth and water status.

Topography has both direct and indirect effects on environmental parameters such as mesoclimate and soil. However, its great importance in terroir studies is apparent when 
a relatively small change in topographic conditions can imprint significant change in wine specificity (Bryan, 2003).

Elevation is by far the most influential topographic characteristic in Slovak viticulture. Annual air temperatures depend mainly on elevation; and Slovakia has the desirable $8^{\circ} \mathrm{C}$ at less than $200 \mathrm{~m}$ elevation required for good grapevines. Production is also possible in $9^{\circ} \mathrm{C}$ average temperature and up to $300 \mathrm{~m}$, and vines can still flourish at $10^{\circ} \mathrm{C}$ and up to $350 \mathrm{~m}$. While lower-situated areas are at risk of inversion freezing, locations above $350 \mathrm{~m}$ are too cold for production (Záruba and Homolová, 1985).

Slope is important in terroir studies because grape growing is restricted unless certain slope conditions are met. Although flat surfaces provide easy work conditions, they are prone to freezing in temperature inversion and therefore not the best option. Producers report that the most suitable slopes range from 5 to $15 \%$; with $25 \%$ the critical value precluding best practice (Jones et al., 2004).

Southern, south-eastern and south-western oriented surfaces in northern hemisphere are the most suitable for grape production. Heliophytes, such as grapevines, thrive in these orientations when exposed to high irradiation in the vegetation period. Slovakia does not have surplus irradiation to cause plant damage; therefore northern, northeastern and north-western aspects here are certainly excluded for premier wines, and used only for fast-ripening and resistant cultivars (Braun and Vanek, 2003).

\section{Material and methods}

\section{Study area}

Slovakia is situated in Central Europe with total area of $49,036 \mathrm{~km}^{2}$. The Republic's northern and central parts are mountainous and follow the Carpathian range, while important lowland agricultural areas are typical in the south and east. These latter localities deliver the entire wine production described in Figure 1.

The $113.74 \mathrm{~km}^{2}$ study area is approximately 30 kilometers north-east of Bratislava and includes the wine settlements of Modra, Dubová, Vištuk, Vinosady and Šenkvice. Prevailing south-east relief is formed by the Danube plains which pass into the highlands of the Malé Karpaty Mts. in the north-west. Slovak Republic viticulture zoning places this rayon in the Small Carpathian Region (Malokarpatská vinohradnícka oblast').

For the Modra wine rayon are typical cool climate conditions. Table 2 depicts basic spatial statistic of local climate which is frequently used for viticultural regions assessment.

Table 2. Spatial statistics for climate variables averaged over the mapped agricultural area of Modra wine rayon Súl'ovský (2017)

\begin{tabular}{c|c|c|c|c}
\hline Variable & Mean & Max & Min & Range \\
\hline Growing season average temperature $\left(\mathrm{GST},{ }^{\circ} \mathrm{C}\right.$ units) & 16.33 & 16.38 & 16.23 & 0.15 \\
Huglin index $\left(\mathrm{HI},{ }^{\circ} \mathrm{C}\right.$ units) & 1895.86 & 1929.38 & 1870.89 & 58.49 \\
Minimal air temperature in January $\left({ }^{\circ} \mathrm{C}\right)$ & -19.38 & -20.50 & -19.11 & 1.39 \\
Mean air temperature in January $\left({ }^{\circ} \mathrm{C}\right)$ & -0.65 & -1.16 & -0.38 & 0.68 \\
Growing season precipitation $(\mathrm{mm})$ & 407.07 & 454.10 & 386.42 & 67.68 \\
\hline
\end{tabular}


The central Modra wine rayon contains significant elevation contrast between the Malé Karpaty Mts. and the Danube plain. The lowest $145 \mathrm{~m}$ area is near the water surface in the southern rayon portion and the $709 \mathrm{~m}$ Vel'ka homol'a hill is in the northwest. Slope impact has previously been described, and this $564 \mathrm{~m}$ difference in 12 $\mathrm{km}$ affects annual air temperature, rainfall and incoming potential global solar radiation. The southern region inclines only 5\%, but the rayon slope is more than $20 \%$ at the foot of the Malé Karpaty Mts. and the greatest slopes are in the mountainous areas where watercourses cross the terrain (Fig. 2). In these localities is sum of the potential global solar irradiation highest (Fig. 3).

Biotite granite dominates the central rayon area at the foot of the Malé Karpaty Mts. The mountains then provide large areas of proluvial sediments, loamy to sandy gravels and alluvial materials; creating the alluvial cones typical of relief in the Modra rayon (Fig. 4). Nearby water flows are several fluvial sediment types with unsorted loams, sandy sediments and loamy-sands. Meanwhile, the southern rayon contains various aeolian and aeolian-delluvial sediments in loess and loess loams. While the prevailing soil type here is Cambisol, the lightest sandy and loamy-sandy soils in the central rayon are mostly related to granite (Fig. 5). Approximately 50\% of the study area has loamy soils with 35 to $45 \%$ humus horizon fractions less than $0.01 \mathrm{~mm}$. Slightly lighter soils with more sand content are in the rayon south-west; mainly in flat areas. The heaviest soils are the clay-loams azonally near water flows and surfaces (VÚPOP, 2015) and the most skeletal granite soils, at 20-25\% in the surface horizon and over 50\% sub-surface, are only in two small localities on the central rayon eastern and western borders. The moderate $20-25 \%$ soils are most common in both layers in the entire non-forested area at the foot of the Malé Karpaty Mts. Soils with the lowest skeleton content of 5 to $25 \%$ in the surface horizon and 10 to $25 \%$ in the subsurface flank the moderate skeletal soils. These granite remnants form a transition from moderate skeletal soils to the nonskeletal soils present on the Danube plain aeolian sediments in the rayon's south.

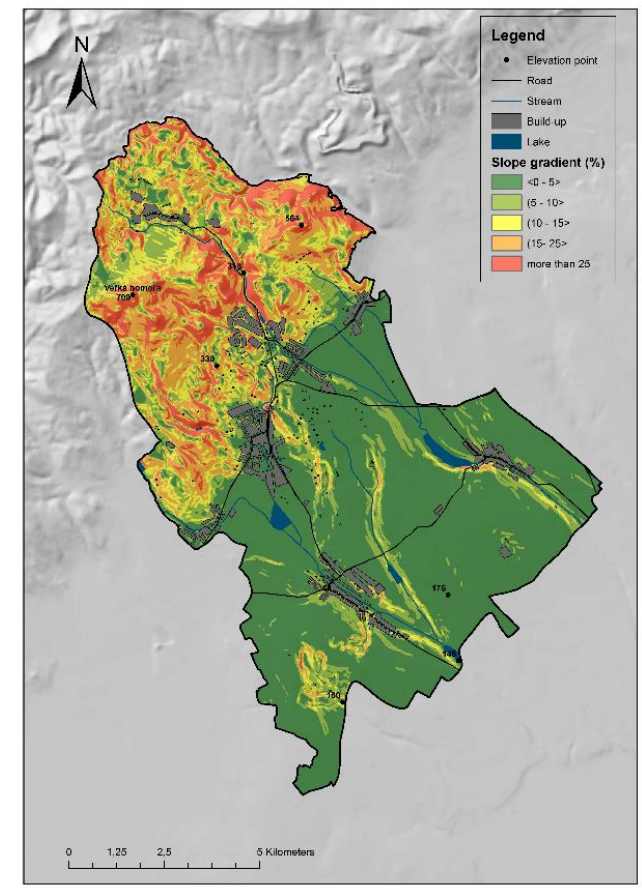

Figure 2. Map showing the slope of the Modra wine rayon 


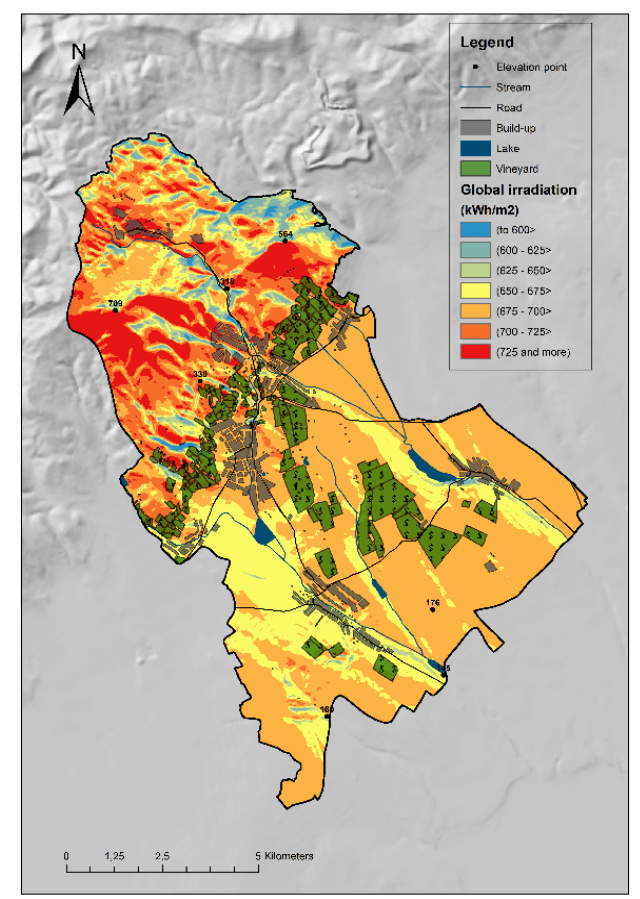

Figure 3. Map showing the slope and potential global irradiation gradient of the Modra wine rayon

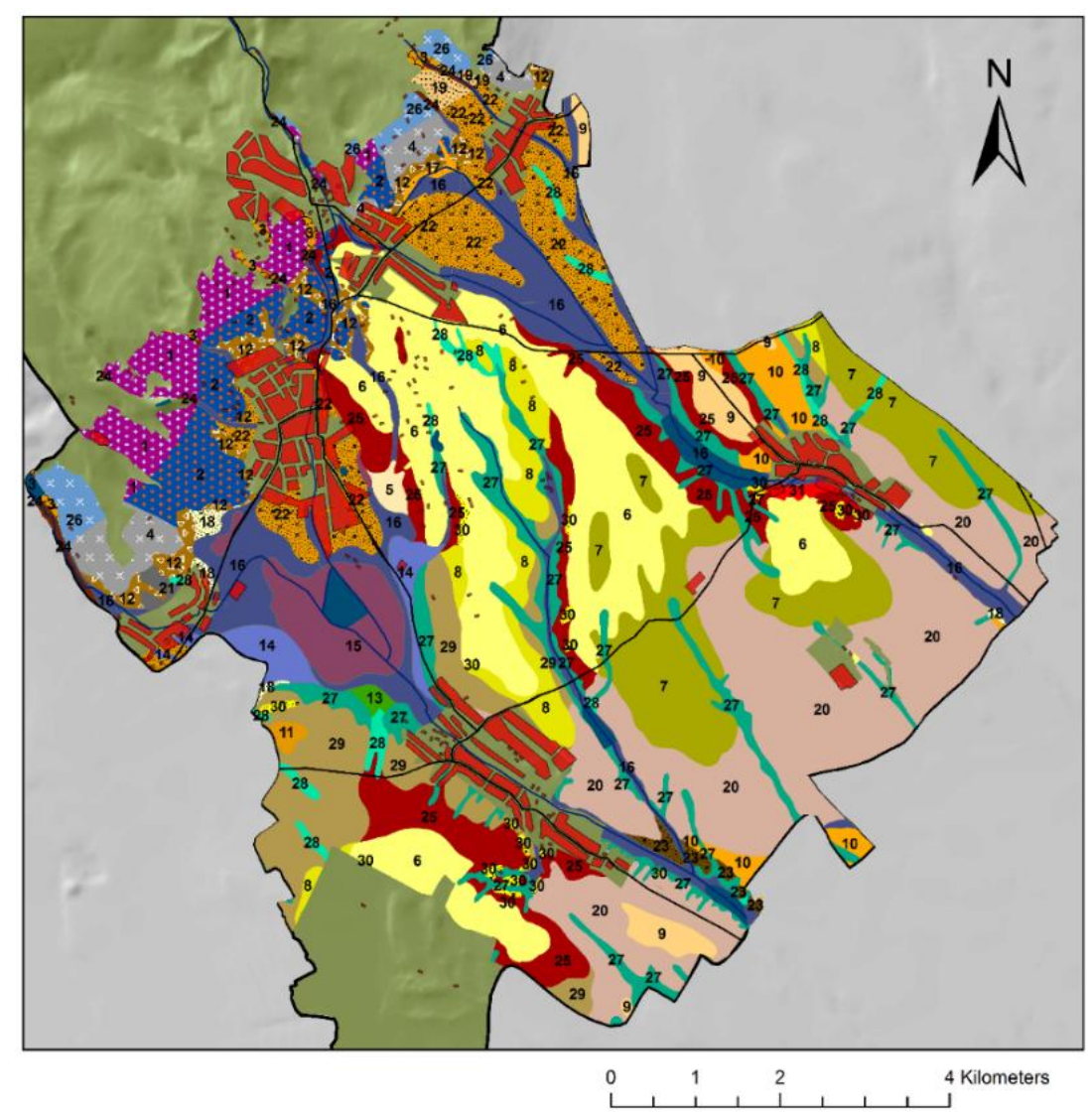

Figure 4. The map showing geological variability in the Modra wine rayon with codes (legend) of geological units included in Table 3 (ŠGÚDŠ, 2013) 


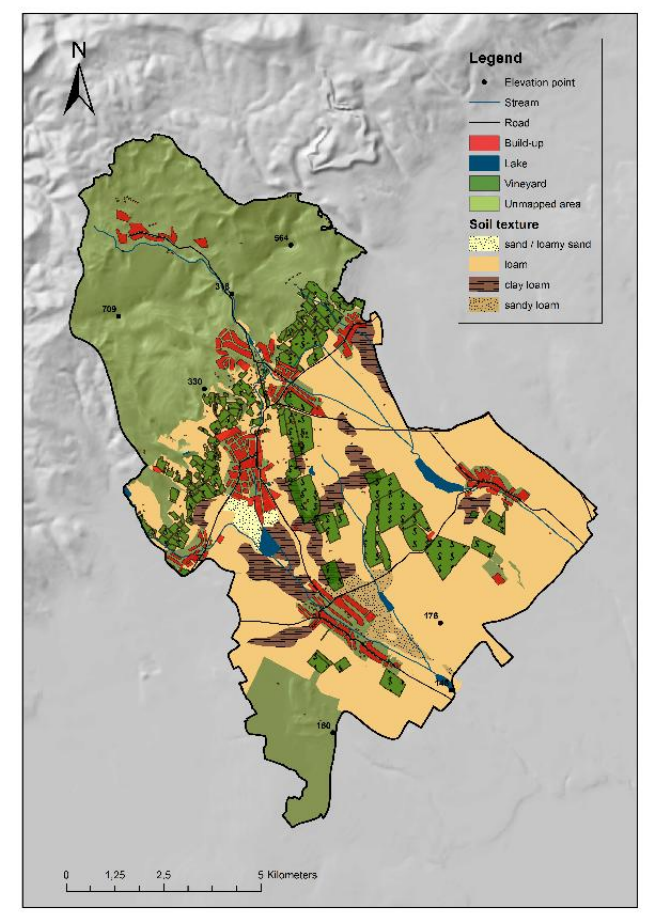

Figure 5. Soil texture in the Modra wine rayon (VÚPOP, 2015)

The following three soil types are present between the surface and the $50 \%$ skeleton content depth: (1) the deepest are at $60 \mathrm{~cm}$ in the lowest flat localities on quarternary Aeolian sediment; (2) soils at 30 to $60 \mathrm{~cm}$ are on alluvium and deluvium cones and (3) shallow soils cover some of the rockiest areas (Fig. 6).

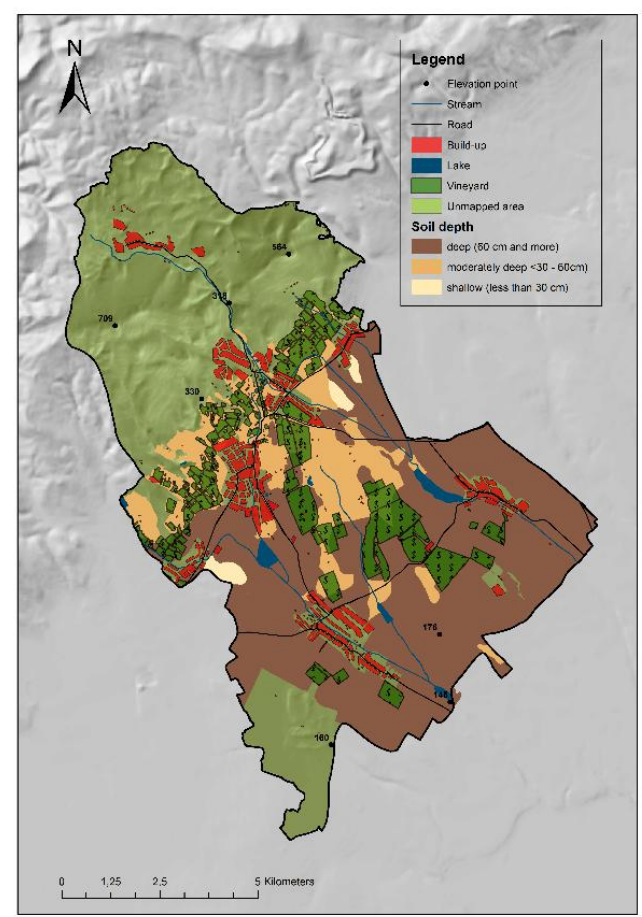

Figure 6. Soil depth in the Modra wine rayon (VÚPOP, 2015) 


\section{Analysis of data}

Agricultural land was chosen for Natural Terroir Units (NTU's) identification because forests and built up areas have no current viticulture potential and from this reason they were masked out. Elevation, Slope, Potential global solar irradiation in vegetation period, Soil texture, Soil skeleton, Soil depth and Geological units were selected and logically reclassified (encoded) in regard to qualitatively high grape production and its limitations using Spatial Analyst tool Reclassify. This tool assign to the initial values new user defined values. All of the new values were ascending ordered for purpose of preservation of logical frame for further analyses and practical usage. Potential global solar irradiation for the vegetation period and slope were derived from digital elevation model (DEM) in ArcGIS 10.1.

Encoding logic and raster interval selection is discussed below in the text. Subsequently, ArcGIS 10.1 spatial analyst tool Combine was used for the final map composition, whereby composition of the analytical maps of natural characteristics identified potential NTU's. Raster output was in next stage converted into vector format using Raster to Polygon conversion tool in ArcGIS 10.1. Final raster composition resulted in over 2,500 created NTU's of which all polygons smaller than 3 ha were removed by clustering with the neighboring NTU's having largest area. It is important to note here, that most of the clustered features were only small sliver polygons which were product of raster composition. This step was carried out using Generalization tool Eliminate in ArcGIS 10.1. Subsequently it was assigned specific key to every NTU of eight digits; with geological conditions comprising the final two digits (Fig. 7). Geology affects bouquet and gives the wine a more specific character than the other elements, and two code digits were necessary to differentiate over nine classes in the geologically complex Modra wine rayon. Figure 8 depicts the NTU map created by overlapping the seven independent environmental factors. Physical-geographical data were verified by field investigation in an integrative geo-ecological approach in the 2015/16 growing seasons (Minár et al., 2001), and vineyard research points were located in individual NTU centroids (Fig. 9).

\section{Encoded elevations}

Elevation values correlate strongly with climate characteristics in study area, so it was more important to encode elevation information in NTU, rather than some other climate aspects. Table 3 has elevation reclassified into the following three intervals; (a) less than $200 \mathrm{~m}$ is numbered 1 in the first code position, because this has relatively high risk of ground frost during vegetation; (b) 200 to $300 \mathrm{~m}$ is numbered 2 as it is optimal for rainfall, temperature and ground freezing risk and (c) all higher areas are numbered 3 because higher rainfalls and lower temperatures make these areas least optimal for growth (Homolová and Kropáč, 1993; Table 4).

\section{Encoded slopes}

Slope is encoded twice; once in the second position as a discrete characteristic, and again as potential global irradiation input. Slope in the former case is subdivided into 4 classes placed in position 3; (a) flat areas with less than 5\% slope are numbered 1 and (b) ideal slope 5.1 to $15 \%$ is numbered 2 (Jones et al., 2004; Sarmento et al., 2006); and these classes led to the delimitation of all intervals (Table 4). 


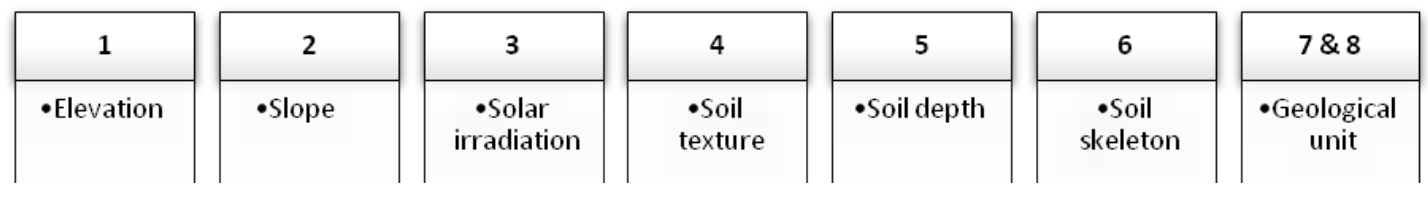

Figure 7. Final composition of the coding system for NTU natural characteristics

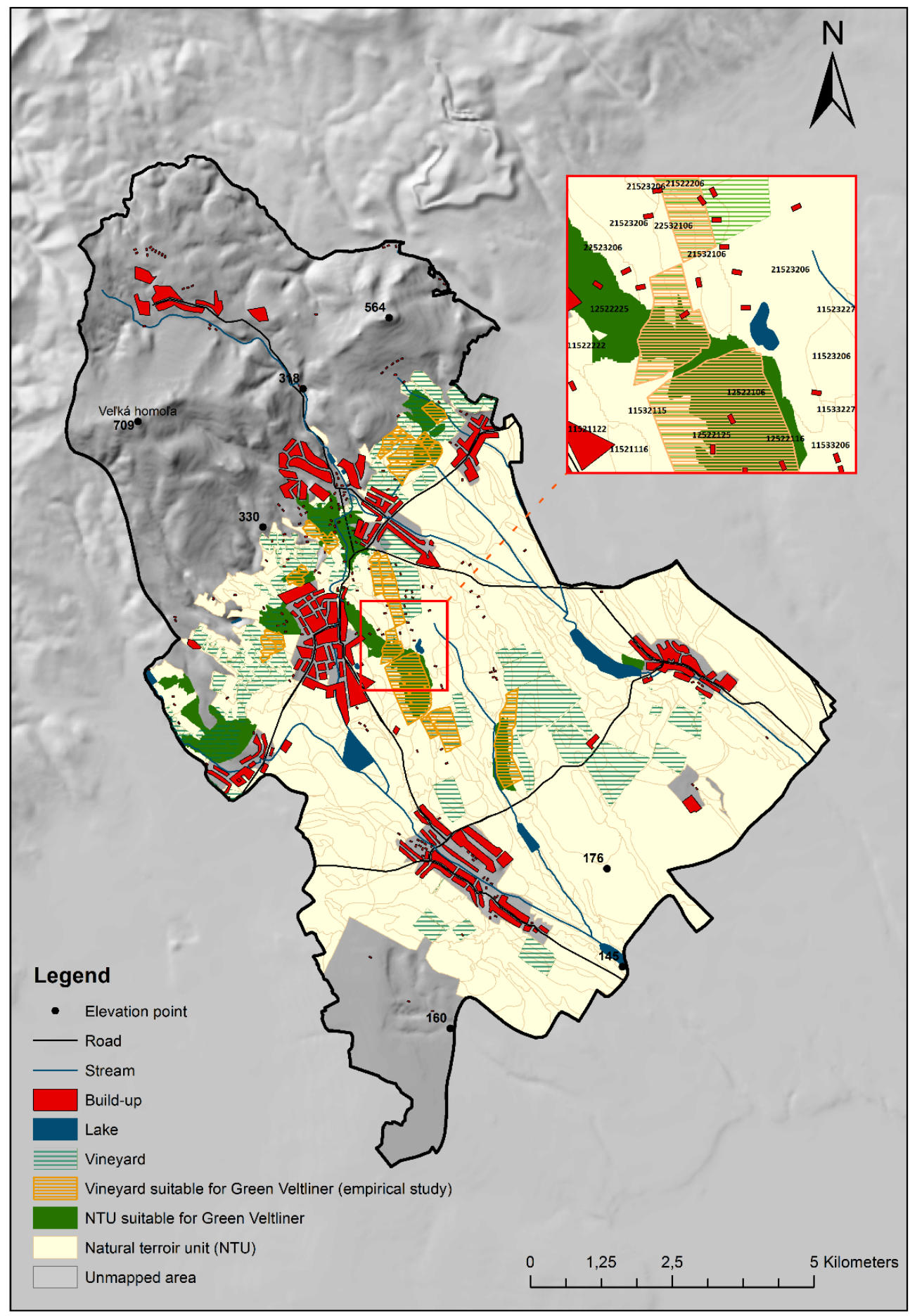

Figure 8. The delimited NTUs of the Modra wine rayon and the most suitable NTUs for Green Veltliner production 

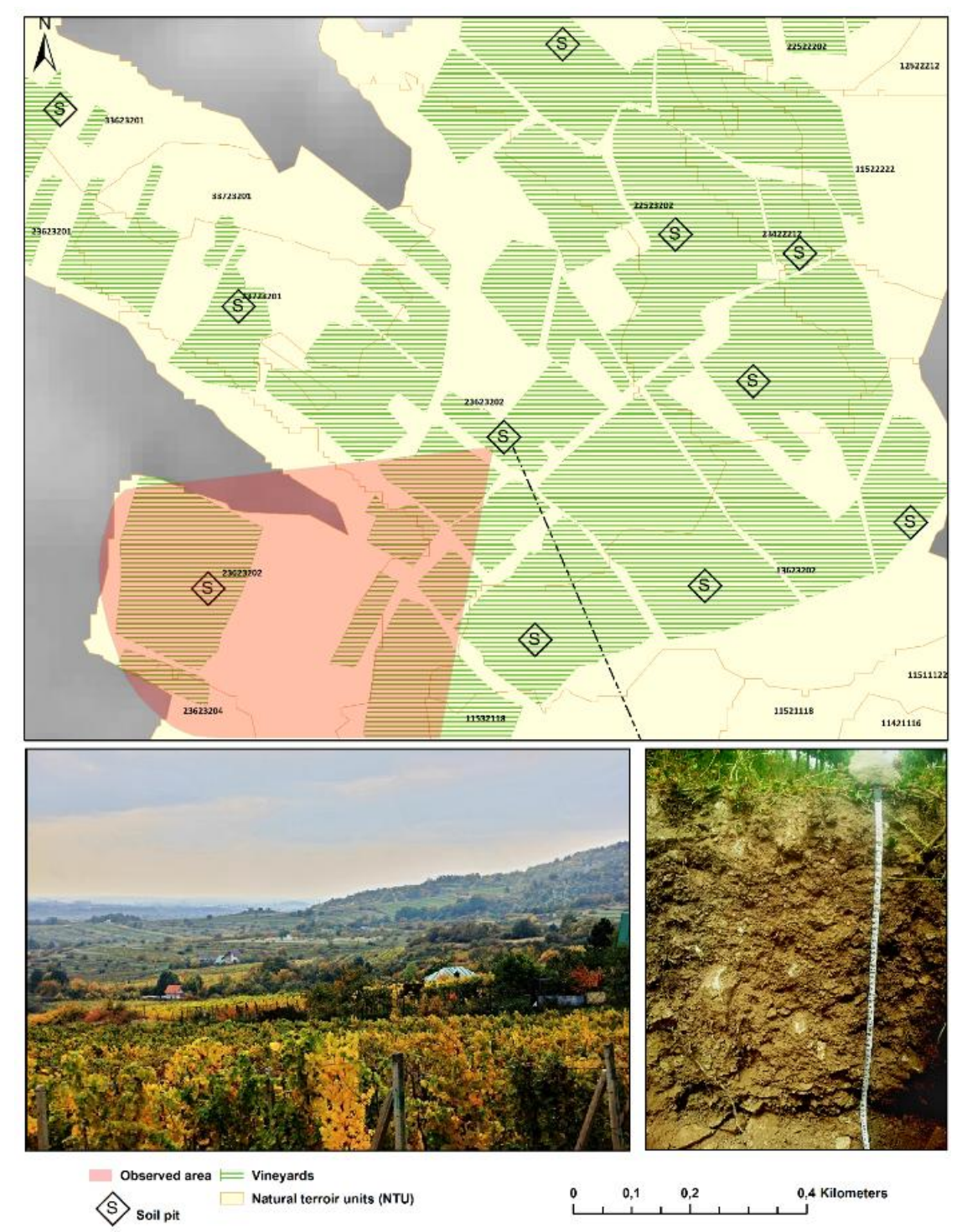

Figure 9. Soil pits localization based on NTU map

Table 3. The illustration of the NTU attribute table that implies values of individual codes of the natural characteristics

\begin{tabular}{c|c|c|c|c|c|c|c}
\hline NTU & Elevation & Slope & Irradiation & Texture & Depth & Skeleton & Geology \\
\hline 33723226 & 3 & 3 & 7 & 2 & 3 & 2 & 26 \\
32622203 & 3 & 2 & 6 & 2 & 2 & 2 & 03 \\
23613226 & 2 & 3 & 6 & 1 & 3 & 2 & 26 \\
23623204 & 2 & 3 & 6 & 2 & 3 & 2 & 04 \\
22523212 & 2 & 2 & 5 & 2 & 3 & 2 & 12 \\
22622222 & 2 & 2 & 6 & 2 & 2 & 2 & 02 \\
22622219 & 2 & 2 & 6 & 2 & 2 & 2 & 19 \\
22522226 & 2 & 2 & 5 & 2 & 2 & 2 & 26 \\
22522222 & 2 & 2 & 5 & 2 & 2 & 2 & 22 \\
\hline
\end{tabular}


Table 4. NTU code system

\begin{tabular}{|c|c|c|c|}
\hline Elevation (m) & Code & Geological unit & Code \\
\hline Less than 200 & $1 \mathrm{xxxxxxx}$ & Biotite granite & $\operatorname{xxxxxxx1}$ \\
\hline 201 to 300 & $2 \mathrm{x} x \mathrm{x} \times \mathrm{xxx}$ & Tonalite & $\mathrm{xxxxxxx2}$ \\
\hline More than 301 & $3 \mathrm{xxxxxxx}$ & Deluvium - mostly loamy and loamy-rocky & $\mathrm{xxxx \times x \times 3}$ \\
\hline Slope $(\%)$ & Code & Phyllite "Harmonia series" & $\operatorname{xxxxxxx} 4$ \\
\hline Less than 5 & $\mathrm{x} 1 \mathrm{xxxxxx}$ & $\begin{array}{l}\text { Loamy and sandy gravels, sands and gravels in floodplain in } \\
\text { alluvial cones }\end{array}$ & $\operatorname{xxxxxxx5}$ \\
\hline 5.1 to 15 & $\mathrm{x} 2 \mathrm{xxxxxx}$ & $\begin{array}{l}\text { Loamy to sandy weathered gravels and rocky fragments in } \\
\text { alluvial cones }\end{array}$ & $\operatorname{xxxxxxx6}$ \\
\hline 15.1 to 25 & $\mathrm{x} 3 \mathrm{x} \times x \times x x$ & $\begin{array}{c}\text { Loamy to sandy weathered gravels and rocky fragments in } \\
\text { alluvial cones with loess surface }\end{array}$ & $\operatorname{xxxxxxx7}$ \\
\hline More than 25 & $\mathrm{x} 4 \mathrm{x} \times \mathrm{xxxx}$ & $\begin{array}{c}\text { Loamy to sandy weathered gravels and rocky fragments in } \\
\text { alluvial cones with loess loam surface }\end{array}$ & $\operatorname{xxxxxxx8}$ \\
\hline $\begin{array}{l}\text { Potential global } \\
\text { irradiation } \\
\left(\mathbf{k W h} / \mathbf{m}^{2}\right)\end{array}$ & Code & $\begin{array}{l}\text { Loamy to sandy-loamy gravels with rocky fragments in } \\
\text { alluvial cones }\end{array}$ & $\operatorname{xxxxxxx} 9$ \\
\hline Less than 600 & $\mathrm{xx} 1 \mathrm{xxxxx}$ & $\begin{array}{c}\text { Loamy to sandy-loamy gravels with rocky fragments in } \\
\text { alluvial cones with loess loam surface }\end{array}$ & $\operatorname{xxxxxx} 10$ \\
\hline$(600$ to $625>$ & $\mathrm{xx} 2 \mathrm{xxxxx}$ & $\begin{array}{c}\text { Loamy to sandy-loamy gravels with rocky fragments in } \\
\text { alluvial cones with loess surface }\end{array}$ & $\operatorname{xxxxxx} 11$ \\
\hline (625 to $650>$ & $\mathrm{xx} 3 \mathrm{xxxxx}$ & Loamy-rocky deluviums and rubbles & $\operatorname{xxxxxx} 12$ \\
\hline$(650$ to $675>$ & $\mathrm{xx} 4 \mathrm{xxxxx}$ & Loams, sandy-loams to loamy-sands in dejection cones & $\operatorname{xxxxxx} 13$ \\
\hline$(675$ to $700>$ & $\mathrm{xx} 5 \mathrm{x} \times \mathrm{xxx}$ & $\begin{array}{l}\text { Loams, sandy-loams to loamy gravels with rocky fragments } \\
\text { in floodplain alluvial cones }\end{array}$ & $\operatorname{xxxxxx} 14$ \\
\hline (700 to $725>$ & $\mathrm{xx} 6 \mathrm{xxxxx}$ & Peat soils & $\operatorname{xxxxxx} 15$ \\
\hline More than 725 & $\mathrm{xx} 7 \mathrm{xxxxx}$ & $\begin{array}{c}\text { Non sorted loams, sandy loams, loamy sands to gravels of } \\
\text { valley rivers and flows }\end{array}$ & $\operatorname{xxxxxx} 16$ \\
\hline Soil texture & Code & Sandy loams to loamy sands with rocky fragments & $\mathrm{xxxxxx} 17$ \\
\hline Sand / loamy sand & $\operatorname{xxx} 1 \mathrm{xxxx}$ & Sandy loams with gravels & $\operatorname{xxxxxx} 18$ \\
\hline Loam & $\mathrm{xxx} 2 \mathrm{xxxx}$ & Sandy gravels (alluvial cones) & $\mathrm{xxxxxx} 19$ \\
\hline Clay loam & $\mathrm{xxx} 3 \mathrm{xxxx}$ & Loess & $\operatorname{xxxxxx} 20$ \\
\hline Sandy loam & $\mathrm{xxx} 4 \mathrm{xxxx}$ & Silts, clays, sands, gravels & $\operatorname{xxxxxx} 21$ \\
\hline Soil skeleton & Code & $\begin{array}{c}\text { Mostly loamy and sandy gravels, sands and sandy loams with } \\
\text { rocky fragments in aluvial cones }\end{array}$ & $\operatorname{xxxxxx} 22$ \\
\hline Without skeleton & $\operatorname{xxxx} 1 \mathrm{xxx}$ & $\begin{array}{l}\text { Mostly loamy and sandy gravels, sands and sandy loams with } \\
\text { rocky fragments in aluvial cones with loess surface }\end{array}$ & $\operatorname{xxxxxx} 23$ \\
\hline Slightly skeletal & $\mathrm{xxxx} 2 \mathrm{xxx}$ & Mostly loamy sediments, non sorted & $\mathrm{xxxx} \times x 24$ \\
\hline Moderate skeletal & $\mathrm{xxx} \times 3 \times x \times$ & Resedimented loamy and sandy-loamy gravels of deluviums & $\mathrm{xxxxx \times} 25$ \\
\hline Highly skeletal & $\mathrm{xxxx} 4 \mathrm{xxx}$ & Seritic-chloritic silliceous phyllite with biotite & $\operatorname{xxxxxx} 26$ \\
\hline Soil depth & Code & $\begin{array}{l}\text { Proluvial-deluvial loams, sandy and clay loam with rocky } \\
\text { fragments }\end{array}$ & $\operatorname{xxxxxx} 27$ \\
\hline Deep & $\mathrm{xxxxx} 1 \mathrm{xx}$ & Proluvial-deuvial loams, sandy loams with graels, gravels & $\mathrm{xxxxxx} 28$ \\
\hline Moderately deep & $\mathrm{xxxxx} 2 \mathrm{xx}$ & Loess loams with loess and soliflued bedrock sediments & $\operatorname{xxxxxx} 29$ \\
\hline \multirow[t]{2}{*}{ Shallow } & $\mathrm{xxxxx} 3 \mathrm{xx}$ & Gravels, sands, sandstones, lignits, coal clays & $\mathrm{xxxxx \times 30}$ \\
\hline & & Different rocks on upheavals & $\operatorname{xxxxxx31}$ \\
\hline
\end{tabular}




\section{Encoded potential global solar irradiation}

In Slovak Republic conditions, it is paramount for grapevines to reach the maximum total solar energy during vegetation. Higher solar irradiation in Italy, Spain and Portugal can promote leaf-burn, but this is extremely unlikely in Slovakia. Table 3 depicts Modra potential global solar irradiation classified in 7 categories; and this element takes the third encoded position. Higher irradiation values enhance production.

\section{Encoded soil properties}

Soil has such a strong place in terroir studies that we encoded three soil characteristics. From original map legends, we designated (a) texture in the fourth encoded position, with four possible categories; (b) skeleton has the fifth position, with skeletal lack signified by the number 1 and (c) depth has the sixth position with three categories; from deep soils numbered 1 to shallow with 3 (Table 4).

\section{Encoded geological unit}

In the Modra wine rayon there is a very complex geological composition defined by 31 classes (Table 4). We decided to retain original geologic map legend, because here applies the same as in soil mapping dataset of Slovak republic and at any time can be these data generalized using by suitable regionalization procedures. Table 3 depicts selection from NTU attribute table.

\section{Results and discussion}

\section{NTU map creation and its strengths}

The final composition of our analytical maps covered 362 discrete areas classified into 182 regional types (Fig. 8). These quasi homogenous areas which differ minimally in one of the seven coded characteristics are Natural Terroir Units (NTU's). High natural condition complexity in the Modra rayon demanded this number of areas; but appropriate encoding enabled easy research use. Our composite NTU maps characterize the viticulture area and grape production better than the following individual maps; (a) climatic maps provide single information on rainfall, annual temperature and wind direction and (b) soil map content is very important; but this product of bedrock, climatic conditions, topographic parameters and many other factors has complex character in the natural terroir. For example; solar irradiation is an absolute limiting threshold in grape production, but it is not directly incorporated in the soil and soil properties. These factors led to NTU map construction which provided a complex view of the natural conditions in our vineyards.

The value and strength of our NTU identification methodology primarily lie in its easy and effective reproduction in global wine-producing regions. Identification data are easy to obtain and comparison between regions is therefore simple. The density and size of the created regions reflect overall environmental heterogeneity; where small thick regions possess greater natural condition heterogeneity and areas less dense and smaller in size signify homogenous natural conditions. Here, we identify and isolate the homogenous areas in this complex mosaic because these are the production sites of authentic wines with specific sensoric characteristics. 
Our methodology drafts an innovative approach for complex terroir terrain research at the plot level (Fig. 9). The NTU map reveals the homogenous areas forming the basic natural elements of complex terroir; both depiction of the natural terroir units and solution to "place of origin" identification. However, these NTUs and their borders must be subsequently refined and modified in the terrain. Two or more NTU are sometimes recognized within a delimited vineyard. These differences should lead to different wine styles if the grapes were separately processed by the same procedures. The NTU map provides reasonable possibility for further spatial reorganization of the vineyard system, and enables dissolution of heterogeneous vineyards into homogenous subdivisions. These then become areas for authentic wines production with strictly given homogenous natural conditions stored in the appellation system; and precisely such areas are planned for development in the Slovak Republic to replace German wine classification. Initial geographic information used in terroir potential studies is usually reclassified or replaced by ranked values; thus limiting combined consideration of the climate, soil and topographic aspects (Boyer and Wolf, 1998; Sarmento et al., 2006).

Our methodology, however, maintains initial landscape information and includes more natural elements; and this complexity proves valuable for further use. Terroirpotential maps of viticulture areas solely classify them into suitable or unsuitable. This categorization not only overshadows, but it also hides, most of the complex information gathered on the viticultural landscape. Therefore, our method of NTU map construction preserves the vast and valuable information for grape growers lost in previous methods. While South African research (Carey et al., 2002) was on smaller scale, our NTU map contains the most detailed soil, geological and topographical available data. This has application advantages including; (a) generalization according to user need and (b) the basis for further terrain research where the geographer can rapidly detect prospective soil pits as further research localities. In addition to the complexity of our NTU map, the spatial data in the specific 8 digit code also provides evidence of the importance of our methodology. This code enables creation of regional and national databases essential for wine producers intending to plant new vineyards. These databases will (a) extract the most influential natural conditions affecting production quality; (b) be easily updated and (c) code system extension will be continuously ongoing from detailed field terroir research. Thus, producers in touch with environmental needs of the desired cultivar will select NTUs with the highest production potential. While unselected units may also be suitable, these localities can be retained for additional cultivars. We have decided to choose the Green Veltliner sample because it is the most widespread cultivar in the Modra wine rayon. Its popularity illustrates selection of the most valuable production areas identified in natural terroir units.

\section{Green Veltliner encoding}

Ampelographic literature cites that the Green Veltliner cultivar provides the best wines on sloping terrain (Pospíśilová et al., 2005a). The following encoding was adopted; (a) we chose number 2 in our second slope-code position; ranging from 5.1 to $15 \%$ slope; (b) this variety is resistant to freezing, so we chose 1 and 2 in the first code position because it is located in the lowest situated rayon areas often subject to spring frost; (c) it prefers sunny locations; so it is in the sunniest 6 and 7 codes in the 3rd position (d) deep and moderately deep soils are best for this variety, so 1 and 2 
were selected in the 5th code position. Shallow soils were not considered because Kraus (1967) confirms these are absolutely unsuitable for qualitative high Green Veltliner production; (e) there is no evidence that skeletal soils are unsuitable for this cultivar. Although they are harder to process, uniform nutrient distribution results in increased overall quality, and the skeleton ensures very suitable surroundings from the thermal and water regime (Kraus, 1967); (f) we retained the last two code digits for geological conditions. Here, organic soils were ineligible for selection because nutrient distribution and water regime render them unproductive (Kraus, 1967).

The remaining geological classes have only informal character; with potential effect on bouquet and wine character. They qualitatively affect production, but have non-assessable production limitation. NTU were subsequently selected from an attribute table using SQL code; and 26 of the 362 areas were selected as the most valuable for Green Veltliner production. These were verified (Fig. 8) by comparing results from decades long-term empirical tests by the globally recognized breeder and enologist Dorota Pospíśilová, Ph.D. and colleagues (Pospíšilová et al., 2005b). These authors drafted the most bonity vineyards in Modra, and the most valuable varieties for each plot. Only the western portion of the Modra wine rayon remains unvalidated because this area was not covered in the research.

\section{Conclusion}

Detailed field research is important in viticulture studies, and this enabled us to identify natural terroir spatial characteristics based on NTU delimitation. This identification provided the following important findings; (a) the enhanced GIS emergence in geographical research; where GIS technology enabled varietal selection in our terroir studies through analyzing topographic, topo-climatic, soil and geological conditions (b) GIS technology combined, reclassified and verified our spatial information; (c) NTU identification delivered important information on the Modra wine rayon; with methodology applicable to every viticulture area (d) this latter knowledge highlights the advantageous application of similar units with similar conditions in further complex terroir research. The high NTU number clearly indicates that Modra wine rayon natural conditions are heterogeneous and quite complex. The complexed 362 unique areas were classified into 182 classes of natural terroir units. Comparison of the study results to empirical research conducted in the Modra wine rayon confirmed our hypothesis that, there exist selected site units (NTU's) which provide valuable environment for qualitatively high wine production considering to other non-selected areas. To identify complex terroir units, it is paramount to know the natural conditions which will be registered in the central appellation system; and our NTUs should be applied as complex terroir units in further research. Slovakia is working on new terroirbased classification system. This applied research output can contribute for further development of terroir classification of Slovak viticulture. Output natural terroir units are able to be processed in the next step using PCA analysis and further clustering in order to get homogenous areas in every surveyed area. But our work is aimed to uncover basic viticultural spatial units (NTU's) and therefore they were not used other multivariate statistics methods. The authors wished to generate a foundation for future terrain including lab analysis of soil samples from NTU's centroids with aim to create management vineyard zonation reflecting its terroir. 
Acknowledgements. The authors thank the wine-growers in the Modra wine rayon for their support, and especially Ing. Dorota Pospíšilová, $\mathrm{PhD}$. for her valuable information and recommendations on methodology verification. This work was created in projects supported by the Scientific Grant Agency of the Ministry of Education of the Slovak Republic and Slovak Academy of Science under VEGA grants 1/0540/16 and 1/0421/16 and under Comenius University Grant n. 398/2016 and under APPV Grant No. 15-0597 " Use of geoecological data in the implemenatation of precision agriculture."

\section{REFERENCES}

[1] Atkinson, J. (2011): Terroir and the Côte de Nuits. - Journal of Wine Research 22: 35-41.

[2] Bonfrante, A., Basile, A., Langella, G., Manna, P., Terribile, F. (2011): A physically oriented approach to analysis and mapping of terroirs. - Geoderma 167-168: 103-117.

[3] Boyer, J., Wolf, T. K. (1998): GIS and GPS indentify viticultural potential. - American Journal of Enology and Viticulture 49: 449.

[4] Boyer, J., Wolf, T. K. (2000): GIS and GPS aid the exploration of Viticultural potential in Virginia. - Vineyard and Winery Management 6: 48-54.

[5] Braun, J., Vanek, G. (2003): Pestujeme vinič (in Slovak). - Nezávislost', Bratislava.

[6] Bryan, B. A. (2003): Physical environmental modeling, visualization and query for supporting landscape planning decisions. - Landscape and Urban Planning 65: 237-259.

[7] California Wine Industry (2016): World Wine Production by Country 2011-2014. California Wine Industry, San Francisco.

[8] Carey, V. A., Archer, E., Saayman, D. (2002): Natural terroir units: What are they? How can they help the wine farmer? - WineLand 2: 86-88.

[9] Carey, V. A. (2005): The use of viticultural terroir units for demarcation of geogrpahical indications for wine production in Stellenbosh and surrounds. - Ph.D. Thesis, Department of Viticulture and Oenology, Stellenbosh University, Stellenbosh.

[10] Carey, V. A., Archer, E., Barbeu, G., Saayman, D. (2008): Viticultural terroirs in Stellenbosch, South Africa. II. The interaction of Cabernet Sauvignon and Sauvignon Blanc with environment. - Journal International des Sciences de la Vigne et du Vin 42: 185-201.

[11] Chen, T. (2011): Using a geographic information system to define regions of grape cultivar suitability in Nebraska. - Master Thesis, Department of Agriculture, University of Nebrasca, Lincoln.

[12] Ďurčová, E. (2013): Slovenské vína na seba v Paríži upútali pozornost' vinárskeho sveta (in Slovak). - Vinič a víno 2: 58-59.

[13] Ďurčová, E. (2014): Naše vína šíria vo svete dobré správy o Slovensku (in Slovak). Vinič a víno 3: 94-96.

[14] Falt’an, V., Pírová, L., Petrovič, F. (2016): Detailed mapping of geocomplexes in the vineyard landscape. - Folia Oecologica 43: 138-146.

[15] Falt’an, V., Krajčírovičová, L., Petrovič, F., Khun, M. (2017): Detailed geoecological research of terroir with the focus on georelief and soil - a case study of Krátke Kesy vineyards. - Ekológia 36: 214-225.

[16] Gladstones, J. (2000): Past and future climatic indices for viticulture. - Australian \& New Zealand Wine Industry Journal 15: 67-73.

[17] Homolová, L., Kropáč, A. (1993): Základy vinohradníctva a zeleninárstva (in Slovak). Príroda, Bratislava.

[18] Hugett, J. M. (2005): Geology and Wine: a review. - Proceedings of the Geologist Association 117: 239-247.

[19] Huglin, P. (1978): New assessment mode of the helio-thermal conditions in vineyards. Comptes Rendus de l'Académie d'Agriculture de France 64: 1117-1126.

[20] Huglin, P., Schneider, Ch. (1986): Biology and Ecology of Grape. - Lavoisier, Paris. 
[21] Imre, S., Mauk, P. (2003): Geology and Wine 12: New Zealand terroir. - Geoscience Canada 36: 145-159.

[22] Incze, J., Novák, J. T. (2016): Identification of extent, topographic characteristics and land abandonment process of vineyard terraces in the Tokaj-Hegyalja wine region between 1784 and 2010. - Journal of Maps 12: 507-513.

[23] Irimia, L., Patriche, C. V. (2010): Evaluating the ecological suitability of the vineyards by using Geographic Information Systems (GIS). - Cercetări Agronomice în Moldova 1: 4958.

[24] Irimia, L., Patriche, C. V., Quenol, H. (2012): Mapping viticultural potential in temperate climate areas. Case study: Bucium vineyard (Romania). - Cercetări Agronomice în Moldova 2: 75-84.

[25] Irimia, L., Patriche, C. V., Quenol, H. (2013): Viticultural potential assessment and natural terroir units delineation using environmental criteria specific to Romanian viticulture. Case study: Urlaţi wine-growing center, Dealul Mare vineyard. - Soil Forming Factors \& Processes from the Temperate Zone 12: 34-37.

[26] Johnson, L., Nemani, R., Hornbuckle, J., Bastiaanssen, W., Thoreson, B., Tisseyre, B., Pierce, L. (2012): Remote Sensing for Viticultural Research and Production. - In: Dougherty, P. (ed.) Geography of Wine. Springer, New York.

[27] Jones, G. V. (2006): Climate and Terroir: Impacts of Climate Variability and Change of Wine. - In: Macqueen, R. W., Meinerd, L. D. (eds.) Fine Wine and Terroir - The Geoscience Perspective. Geoscience Canada Reprint Series Number 9, Geological Association of Canada, St. John's.

[28] Jones, G. V., Duff, A. (2003): The climate and landscape potential for quality wine production in the Snake River Valley AVA. - Open report to the Idaho Wine Commision.

[29] Jones, G. V., Snead, N., Nelson, P. (2004): Geology and wine 8. Modeling viticultural landscapes: A GIS analysis of the terroir potential in the Umpqua Valley of Oregon. Geoscience Canada 31: 167-181.

[30] Kraus, V. (1967): Vinohradnictví - biologické základy agrotechniky révy vinné (in Czech). - Státní Pedagogické Nakladatelství, Praha.

[31] Magarey, R., Seem, R., De Gloria, S. (1998): Prediction of vineyard site suitability. Grape Res News 9: 1-2.

[32] Masný, M., Zaušková, L. (2015): Multi-temporal analysis of an agricultural landscape transformation and abandonment (Lubietová, Central Slovakia). - Open Geosciences 7: 888-896.

[33] Minár, J. (2003): Detailed physical-geographical (geoecological) research and mapping in the landscape ecology. - Ekológia 22: 141-149.

[34] NRSR (National Council of the Slovak Republic) (2009): Act 313/2009 about viticulture and winemaking.

[35] Pospíśilová, D., Sekera, D., Ruman, T. (2005a): Ampelografia Slovenska (in Slovak). VŠSVVM, Modra.

[36] Pospíšilová, D., Sekera, D., Šimora, R. (2005b): Vypracovanie zonalizácie viniča obce Modra (in Slovak). - Viticultural Breeding Research Institute, Modra.

[37] Sarmento, E., Weber, E., Hasenack, H., Tonietto, J., Mandelli, F. (2006): Topographic modeling with GIS at Serra Gaúcha, Brazil: elements to study viticultural terroir. Proceedings of the Terroir Viticoles Congrès International 6: 365-372.

[38] ŠGÚDŠ (2013): Geological Map of the Slovak Republic (1:10 000). - ŠGÚDŠ, Bratislava.

[39] Súl'ovský, M. (2017): Detailný geoekologický výskum stanovištných podmienok vinohradov v Malokarpatskej vinohradníckej oblasti (in Slovak). - Ph.D. Thesis, Department of Physical Geography Faculty od Natural Sciences, Comenius University, Bratislava.

[40] Tomasi, D., Gaiotti, F., Jones, G. V. (2013): The Power of Terroir: the Case Study of Prosecco Wine. - Springer, Amsterdam. 
[41] Ubalde, J., Sort, X, Zayas, A., Poch, R. (2010): Effect of soil and climatic conditions on grape ripening and wine quality of Cabernet Sauvignon. - Journal of Wine Research 21: $1-17$.

[42] ÚKSUP (2015): Vineyard Register. - ÚKSUP, Bratislava.

[43] Vadour, E. (2002): The quality of grapes and wine in relation to geography: notions of terroir at various scales. - Journal of Wine Research 13: 117-141.

[44] Van Leeuwen, C. (2010): Soils and Terroir Expression in Wines. - In: Landa, E. R., Feller, Ch. (eds.) Soil and Culture, Springer, Dordrecht.

[45] Van Leeuwen, C., Friant, P., Choné, X., Tregoat, O., Koundouras, S., Doubourdieu, D. (2004): Influence of climate, soil, and cultivar in terroir. - American Journal of Enology and Viticulture 55: 207-217.

[46] VÚPOP (2015): Rated Soil Ecological Units - Maps (BPEJ) - VÚPOP, Bratislava.

[47] Záruba, F., Homolová, L. (1985): Vinohradníctvo (in Slovak). - Príroda, Bratislava. 